Bull. Chem. Soc. Ethiop. 2012, 26(3), 353-360.

Printed in Ethiopia

ISSN 1011-3924

DOI: http://dx.doi.org/10.4314/bcse.v26i3.4

(c) 2012 Chemical Society of Ethiopia

\title{
A COMPARATIVE STUDY OF VOLATILE COMPONENTS OF PROPOLIS (BEE GLUE) COLLECTED FROM HARAMAYA UNIVERSITY AND ASSELA BEEKEEPING CENTERS, ETHIOPIA
}

\author{
Kesatebrhan Haile $^{1}$, Tesfahun Kebede ${ }^{1}$ and Aman Dekebo ${ }^{2 *}$ \\ ${ }^{1}$ Department of Chemistry, Haramaya University, P.O. Box 203, Haramaya, Ethiopia \\ ${ }^{2}$ Department of Chemistry, Adama Science and Technology University, P.O. Box 1888, Adama, \\ Ethiopia
}

(Received January 2, 2012; revised May 30, 2012)

\begin{abstract}
The investigation of the volatile compounds of essential oils of propolis from two geographic origins of Ethiopia (Haramaya and Assela) was made by GC-MS. A total of 62 components of the oil were identified from both samples. The identified constituents of the oils may be divided into seven different groups: oxygenated monoterpenes (29.81\% Haramaya, 9.45\% Asella), sesquiterpenes (15.20\% Haramaya, 19.05\% Assela), oxygenated sesquiterpenes (11.86\% Haramaya, $18.56 \%$ Assela), aromatic (14.93\% Haramaya, $4.25 \%$ Assela), oxygenated aromatic (17.59\% Haramaya, $4.58 \%$ Assela), aliphatic (5.06\% Haramaya, 7.62\% Assela) and oxygenated aliphatic (7.84\% Haramaya, $25.17 \%$ Asella). The major volatile compounds of Haramaya propolis consist of calamenene (13.82\%), 4-terpineol (8.57\%), epi-bicyclosesquiphellandrene (8.37\%), 4-(2-acetyl-5,5dimethylcyclopent-2-enylidene)butan-2-one $(7.83 \%)$ and 3-isopropyl-6-methyl-2-oxo-1-(3-oxobutyl)-cyclohexanecarbaldehyde (5.90\%). Whereas the most abundant constituents of Assela propolis were 5,6,7,8tetramethylbicyclo[4,1,0]hept-4-en-3-one $(15.01 \%)$, acoradien $(13.77 \%)$, epicedrol $(6.80 \%)$ and $(6 E, 6 E)$ 3,7,11,15-tetramethyl-1,6,10,14-hexadecatetraen-3-ol (6.14\%). Ten compounds which were found in both samples of propolis were trans-pinocarveol, $\alpha$-cadinol, cis-verbenol, $\alpha$-campholenal, 4 -terpineol, $p$-cymen- 8 -ol, $p$ menth-1-en-8-ol, epi-bicyclosesquiphellandrene, calamenene and 3-isopropyl-6-methyl-2-oxo-1-(3-oxobutyl)cyclohexanecarbaldehyde.
\end{abstract}

KEY WORDS: Propolis, Bee glue, Monoterpene, Sesquiterpene, Calamenene, 4-Terpineol

\section{INTRODUCTION}

Propolis (bee glue) is a sticky dark-colored material that honeybees (Apis mellifera) collect from living plants, mix it with wax and use it in the construction and adaptation of their nests, mainly to fill out cracks in the bee hive. It also serves to repair the hive, to seal openings in the hive and to eliminate contaminating microorganisms in the hive [1, 2]. Propolis is not only a building material; it is the most important "chemical weapon" of bees against pathogen microorganisms and has been used as a remedy by humans since ancient times. It is still one of the most frequently used remedies in the Balkan states, applied for treatment of wounds, burns, sore throat and stomach ulcer [3].

The word propolis was probably coined by Aristotle from the Greek words "pro" meaning "in front of" and "polis" meaning "city". The combined meaning then becomes "In front of the City" or "Defender of the City (or Beehive)" and this is how bees use propolis. It has been used in folk medicine since ancient times and is now known to be a natural medicine with antibacterial, antifungal, anaesthetic, antitumoral, antioxidative, anti-inflammatory, imunomodulatory, cancer prevention, anti-viral, anti-yeast, antimicrobial, and cardiovascular and other beneficial activities [4].

With the advent of modern chromatographic techniques frequently associated with mass spectrometry (MS), many compounds have been isolated and identified in propolis [5]. But the complex chemical composition of propolis is frequently updated due to many regional

*Corresponding author. E-mail: aman_d00@yahoo.com 
variations. More than 300 propolis constituents have been identified using different chromatographic and spectroscopic techniques including chromatography-mass spectrometry (GC-MS). Among them, the volatile compounds are great important due to their potent biological activities.

Propolis is composed of 50\% resin (polyphenolic fraction) and balsam (cream), 30\% wax, $10 \%$ essential and aromatic oils, 5\% pollen, and 5\% other substances [6]. Literature survey revealed that flavonoids, aromatic acids, diterpenic acids and phenolic compounds appear to be the principal components of propolis samples. The properties and actual contents of propolis depend on the collecting location of the bees, time of year and plant source [7]. For many years, GC-MS has been used for the detailed analysis of the main volatile and semi-volatile components of propolis $[8,9]$. As volatile components, various mono and sesquiterpenes are found in propolis $[10,11]$. Other constituents of volatile oils include alcohols, mainly aromatic alcohols, phenols, aldehydes, ketones, acids (from acetic to stearic acid), esters, a series of alkanes, alkylated benzenes and naphthalene [10].

The great variability in chemical composition of the propolis from different regions is because honeybees extract raw materials from different plants in different ecosystems for their production of propolis [12]. Crude ethanol extract of propolis collected from Egypt and South Africa showed antimicrobial activity against a wide range of pathogenic bacteria, fungi, yeasts and viruses $[13,14]$.

Knowledge of volatile components of propolis is so important as its oil exhibited antibacterial activity against Staphylococcus aureus, Staphylococcus epidermides, Streptococcus pyogenes and Escherichia coli and also used for special flavor and cosmetics [15].

This study compares volatile compounds of propolis collected from Haramaya University and Assela Beekeeping Centers. Only one study has been previously reported on Ethiopian propolis collected from Holeta Beekeeping Centers on gastro protective effect of crude ethanol extract of propolis against chemical induced gastric mucosal lesions in mice [16]. However, there has been a research gap to date on GC-MS analysis of essential oil composition of Ethiopian propolis. Besides, the chemical composition of propolis as well as its color, aroma and probably its medicinal characteristics are changed according to the geographical zones and the season of the year.

\section{EXPERIMENTAL}

\section{Description of the study area}

Haramaya University is located at a latitude of $9^{\circ} 20^{\prime}$ north of the equator and $42^{\circ} 03^{\prime}$ longitude east of meridian. The university has a total area of about $46 \mathrm{~km}^{2}$. It has a moderate average temperature of $16{ }^{\circ} \mathrm{C}$, and the mean maximum and minimum annual temperature is 24.02 and $9.73{ }^{\circ} \mathrm{C}$, respectively [17]. The mean annual rainfall is $780 \mathrm{~mm}$. The $1980 \mathrm{~m}$ elevation of the area (Weinadega) ensures that it enjoys a relatively moderate and pleasant climate throughout the year. There were 12 beehives in the university. Among these 5 hives are traditional and 7 of them are modern beehives. Eucalyptus glublus, Eucalyptus camnadulesis (exotic), Vernonia amygdalina (indigenous), Spathodea nilotica (exotic), Jacaranda mimosifolia (exotic), Pinus radiate (exotic), Olea africana, Cordial africana and Grevillea robusta are dominant plants and vegetations in Haramaya [18].

Adama University Assela School of Agricultural Campus is located at $7^{\circ} 57^{\prime}$ north and $39^{\circ} 8^{\prime}$ east and has an altitude of $2400 \mathrm{~m}$ above sea level. The site has a bimodal rainfall pattern with a mean annual precipitation of about $725 \mathrm{~mm}$. The mean minimum and maximum temperature of the area were $8.28{ }^{\circ} \mathrm{C}$ and $23.3{ }^{\circ} \mathrm{C}$, respectively [19]. There were 19 beehives in Assela School of Agricultural Campus. Among these 2 hives are traditional and 17 of them are 
modern beehives. The dominant plants in Assela are Eucalyptus glublus, Eucalyptus camnadulesis (exotic), Haginia abyssinica (endemic), Croton macrostachyus (indigenous), Vernonia amygdalina (indigenous), Ekebergia capensis and Acacia mearnsii dewild [19].

\section{Propolis samples collection}

Samples of propolis ( $400 \mathrm{~g}$ ) were collected by hand (by scrapping from frames and walls of the beehives) from Haramaya University and Assela Beekeeping Sections from September 2009 to November 2009 and kept in the refrigerator until processed.

\section{Hydro-distillation}

A $100 \mathrm{~g}$ portion of each of propolis samples collected from Haramaya and Assela beekeeping centers was hydro-distilled separately using a Clevenger's apparatus (Bibby Sterilin Ltd, Quickfit, England) for $3 \mathrm{~h}$. The oil was separated in a separatory funnel. The aqueous portion was extracted twice with chloroform (99.96\%, analytical reagent, Fisher Scientific UK Limited). The oil obtained as such was dried over anhydrous $\mathrm{Na}_{2} \mathrm{SO}_{4}$, filtered using Whatmann No. 1 filter paper, concentrated under vacuum and weighed to yield 0.64 and $0.48 \mathrm{~g}$ for Haramaya and Assela, respectively. The oil was kept at $4{ }^{\circ} \mathrm{C}$ until analysis [20]. The chemical constituents of the oils were determined by GC-MS at the laboratory of Quality and Standards Authority of Ethiopia.

\section{GC-MS analysis of the essential oils of propolis}

GC-MS instrument from Agilent Technologies (Santa Clara, CA, USA) was equipped with a $6890 \mathrm{~N}$ network GC system, 5975 inert mass selective detector, 7683B series autosampler injector $\left(10 \mu \mathrm{L}\right.$ in size), G1701DA GC/MSD ChemStation and $\mathrm{HP}_{5} \mathrm{MS}$ column (30 m length $\mathrm{x}$ $0.25 \mathrm{~mm}$ internal diameter $\mathrm{x} 0.25 \mu \mathrm{m}$ film thickness) coated with $5 \%$ phenyl $95 \%$ methyl poly siloxane. Two $\mu \mathrm{L}$ essential oil solution in chloroform was injected through autosampler and analyzed with $\mathrm{HP}_{5} \mathrm{MS}$ column.

Column temperature was programmed as follows [20]: 55 to $120{ }^{\circ} \mathrm{C}$ at $20{ }^{\circ} \mathrm{C} / \mathrm{min}, 120$ to $150{ }^{\circ} \mathrm{C}$ at $1.5{ }^{\circ} \mathrm{C} / \mathrm{min}, 150$ to $250{ }^{\circ} \mathrm{C}$ at $20{ }^{\circ} \mathrm{C} / \mathrm{min}, 250{ }^{\circ} \mathrm{C}(10 \mathrm{~min})$ and $3 \mathrm{~min}$ solvent delay. Mass spectra transfer line temperature was $280{ }^{\circ} \mathrm{C}$. Carrier gas was helium $(1 \mathrm{~mL} / \mathrm{min})$ with a split ratio equal to 100:1. Injector, quadrupole and detector temperatures were 220,150 and 250 ${ }^{\circ} \mathrm{C}$, respectively. The mass spectra were recorded in electron ionization (EI) mode at $70 \mathrm{eV}$ with scanning from 50 to $500 \mathrm{amu}$ at $0.5 \mathrm{~s}$ and mass source was set at $230{ }^{\circ} \mathrm{C}$.

The identification of the compounds was based on retention indices, by computer search using a combination of NIST2005 library, retention time $\left(t_{R}\right)$ and by comparison with the spectra data in the literature. Integration of peaks was performed using Hewlett Packard ChemStation software (G1701BA Version B.01.00).

\section{RESULTS AND DISCUSSION}

\section{Essential oil composition of propolis}

The chemical composition of propolis is dependent on its geographical location; as a result, its biological activity and chemical composition is closely related to the vegetation native to the site of collection [21]. The compounds in essential oils include hydrocarbons (monoterpines, sesquiterpenes, and aromatics), oxygenated compounds (aromatics, phenols, alcohols, sesquiterpene alcohols, aldehydes, ketones, esters, lactones, ethers, oxides, etc.) and others [22].

The hydrodistillation of propolis collected from Haramaya and Assela yielded a clear yellowish essential oil $1.2 \%$ and $0.92 \%$ (w/w), respectively. GC-MS analysis of essential oils of Haramaya and Assela propolis has shown 43 and 47 components, respectively. From these, 31 
compounds for each origin were identified by means of their retention times, retention indices, by comparison with the spectra data in the literature and mass spectral fragmentation patterns and by comparing their mass spectra with the NIST 2005 library of mass spectra, representing $95.16 \%$ and $91.66 \%$ of the total oil for Haramaya and Assela propolis, respectively. Unidentified components were present in such low amounts that either no mass spectrum could be recorded or the spectrum was too poor for interpretation.

The major volatile compounds of Haramaya propolis consist of calamenene (13.82\%), 4terpineol (8.57\%), epi-bicyclosesquiphellandrene (8.37\%), 4-(2-acetyl-5,5-dimethylcyclopent-2enylidene) butan-2-one (7.83\%) and 3-isopropyl-6-methyl-2-oxo-1-(3-oxobutyl)-cyclohexanecarbaldehyde $(5.90 \%)$. These components contribute about $44.50 \%$ of the total oil for Haramaya propolis (Table 1). Whereas the most abundant constituents of Assela propolis which represent $41.72 \%$ of the total oil, were 5,6,7,8-tetramethylbicyclo[4,1,0]hept-4-en-3-one $(15.01 \%)$, acoradien (13.77\%), epicedrol $(6.80 \%)$ and (6E,6E)-3,7,11,15-tetramethyl-1,6,10,14hexadecatetraen-3-ol $(6.14 \%)$ as shown in Table 2 . The great variability in chemical composition of essential oils of propolis obtained from Haramaya beehives from that of Assela might have been caused by the action of Apis mellifera monticola (propolis collecting Honeybee race in Assela) and Apis mellifera jementica (propolis collecting Honeybee race in Haramaya). Southeast Ethiopia is dominated by Apis mellifera monticola [23]. Apis mellifera jementica is a type of bee species that collects propolis in the eastern, semi-arid lowlands and northwest low land areas of Ethiopia [24]. These honeybees race added other materials during the production of propolis from different plants depending on the geographic location. The plant sources of identified compounds from both samples remain unknown in the present study. However,

Baccharis dracunculifolia, Araucaria angustifolia, Araucaria heterophylla, Clusia minor and Eucalyptus citriodora are the main sources of the bee glue in Brazil [25].

A comparison of the results of this work with those of previously reported for essential oil composition of propolis reveals significant differences. The Iranian propolis essential oil (Lalehzar origin) was found to be rich in $\alpha$-pinene $(43.9 \%), 1,8$-cineole $(11.1 \%)$, camphene $(8.6 \%), \beta$-myrcene $(3.9 \%)$, broneol $(3.4 \%)$, camphor $(2.4 \%)$ and verbenol $(2.3 \%)$ where as the Propolis essential oil of Kerman origin contains $\alpha$-pinene $(46.1 \%), 1,8$-cineole $(11.1 \%)$, camphene $(9.6 \%)$, camphor $(5.3 \%)$, sabinene $(4.6 \%), \beta$-myrcene $(3.9 \%)$, broneol $(3.4 \%)$, bornyl acetates $(2.8 \%)$, verbenone $(2.3 \%)$ and linalool $(2.1 \%)$ [26]. Moreover, the most abundant components in Brazilian propolis essential oil were $\beta$-caryophyllene (12.7\%), acetophenone $(12.3 \%)$, farnesene $(9.2 \%)$ and linalool $(6.47 \%)$, followed by $\gamma$-elemene $(6.25 \%), \gamma$-cadinene $(5.86 \%)$ and $\gamma$-muurolene $(3.61 \%)$ [15].

In this study, the identified components may be divided into seven different groups (Table 1 and 2): oxygenated monoterpenes (29.81\% Haramaya, 9.45\% Assela), sesquiterpenes $(15.20 \%$ Haramaya, 19.05\% Assela), oxygenated sesquiterpenes (11.86\% Haramaya, 18.56\% Assela), aromatic (14.93\% Haramaya, 4.25\% Assela), oxygenated aromatic (17.59\% Haramaya, 4.58\% Assela), aliphatic (5.06\% Haramaya, $7.62 \%$ Assela) and oxygenated aliphatic $(7.84 \%$ Haramaya, $25.17 \%$ Assela).

From the 62 identified volatile compounds, ten were present in both oils. These were transpinocarveol, 3-isopropyl-6-methyl-2-oxo-1-(3-oxobutyl)-cyclohexanecarbaldehyde, calamenene, cis-verbenol, 4 -terpineol, $\quad p$-cymen-8-ol, $\alpha$-campholenal, $\alpha$-cadinol, epi-bicyclosesquiphellandrene and $p$-menth-1-en-8-ol. Similarly, $\alpha$-pinene $(11.90 \%)$, trans-verbenol $(7 \%)$, hexadecanoic acid $(10.9 \%)$, limonene $(0.62 \%)$, trans-pinocarveol $(0.33 \%)$, cis-verbenol $(0.20 \%)$, camphor $(<0.01 \%)$, borneol $(<0.01 \%)$, terpinen-4-ol $(0.03 \%)$, p-cymen-8-ol $(<0.01 \%)$, verbenone $(0.55 \%)$, trans-carveol $(0.08 \%), \alpha$-cadinene $(0.04 \%), \alpha$-cadinol $(0.17 \%)$, heptadecane $(0.16 \%)$ and $\alpha$-campholenal $(0.15 \%)$ were the volatile constituents of propolis collected from Mexico (Yucatan origin) [27]. The percentage composition of each compound in the oils of the two sample collection sites was different as shown in Table 3. 
Table 1. Chemical composition of essential oils of propolis obtained from Haramaya beehives analyzed by GC-MS.

\begin{tabular}{|c|c|c|c|c|}
\hline Compound & $t_{R}(\min )$ & RI(iu) & RI Lit. & Comp. (\%) \\
\hline \multicolumn{5}{|l|}{ Monoterpenes } \\
\hline 6,6-Dimethyl-2-methylenebicyclo[3,1,1]heptane & 3.244 & 943 & --- & 0.43 \\
\hline Limonene & 3.992 & 1014 & 1014 & 0.29 \\
\hline \multicolumn{5}{|l|}{ Oxygenated Monoterpenes } \\
\hline$\alpha$-Campholenal & 5.054 & 1155 & 1123 & 1.37 \\
\hline trans-Pinocarveol & 5.266 & 1128 & 1136 & 3.21 \\
\hline cis-Verbenol & 5.314 & 1131 & 1138 & 4.47 \\
\hline Camphor & 5.361 & 1121 & 1136 & 3.23 \\
\hline$\alpha$-Phellandren-8-ol & 5.601 & 1131 & 1005 & 2.72 \\
\hline 4-Terpineol & 5.792 & 1182 & 1184 & 8.57 \\
\hline p-Menth-1-en-8-ol & 5.973 & 1143 & --- & 2.87 \\
\hline cis-Carveol & 6.404 & 1203 & 1225 & 2.03 \\
\hline cis-p-Menth-2,8-dienol & 9.560 & 1104 & --- & 1.36 \\
\hline \multicolumn{5}{|l|}{ Sesquiterpenes } \\
\hline (+)-Epi-bicyclosesquiphellandrene & 13.206 & 1470 & --- & 8.37 \\
\hline Epizonarene & 14.549 & 1538 & --- & 1.34 \\
\hline$\alpha$-Himachalene & 20.656 & 1450 & 1448 & 4.52 \\
\hline$\delta$-Cadinene & 21.192 & 1497 & 1522 & 0.97 \\
\hline \multicolumn{5}{|l|}{ Oxygenated Sesquiterpenes } \\
\hline$\alpha$-Cedrene oxide & 16.082 & 1579 & --- & 2.19 \\
\hline Cedrol & 19.185 & 1580 & 1536 & 2.48 \\
\hline $\begin{array}{l}\text { 3-Isopropyl-6-methyl-2-oxo-1-(3-oxobutyl)- } \\
\text { cyclohexanecarbaldehyde }\end{array}$ & 20.556 & 1905 & --- & 5.90 \\
\hline$\alpha$-Cadinol & 21.889 & 1632 & 1641 & 1.29 \\
\hline \multicolumn{5}{|l|}{ Aromatic } \\
\hline$o$-cymene & 3.950 & 1028 & 1022 & 1.10 \\
\hline Calamenene & 15.620 & 1517 & 1520 & 13.82 \\
\hline \multicolumn{5}{|l|}{ Oxygenated aromatic } \\
\hline 3-Thujen-2-one & 5.701 & 1170 & 884 & 3.14 \\
\hline$p$-Cymen-8-ol & 5.864 & 1158 & 1180 & 3.37 \\
\hline Verbenone & 6.326 & 1191 & 1195 & 2.13 \\
\hline$\alpha$ - Terpineol acetate & 9.296 & 1334 & 1345 & 1.11 \\
\hline \multicolumn{5}{|l|}{ Aliphatic } \\
\hline 4a-Methyl-1,2,3,4,4a,5,6,7-octahydronaphthalene & 7.752 & 1185 & -- & 2.32 \\
\hline Cadala-1(10),3,8-triene & 16.461 & 1423 & --- & 1.54 \\
\hline 1-Nonadecene & 25.980 & 1885 & $\begin{array}{ll}-- \\
\end{array}$ & 0.57 \\
\hline 1-Eicosene & 27.958 & 1997 & 1994 & 0.38 \\
\hline 1-Docosene & 29.355 & 2188 & --- & 0.25 \\
\hline \multicolumn{5}{|l|}{ Oxygenated aliphatic } \\
\hline $\begin{array}{l}\text { 4-(2-Acetyl-5,5-dimethylcyclopent-2- } \\
\text { enylidene)butan-2-one }\end{array}$ & 23.566 & 1560 & --- & 7.83 \\
\hline
\end{tabular}

$\mathrm{t}_{\mathrm{R}}(\mathrm{min})=$ retention time, $\mathrm{RI}=$ retention Index, $\mathrm{RI}$ lit $=$ retention index literature, Comp. $=$ composition.

According to the previous study [28], thujone (0.1\%), thymol (not determined (ND)), limonene $(6.1 \%)$, trans-pinocarveol $(0.4 \%)$, cis-verbenol $(0.4 \%)$, camphor $(0.1 \%), p$-cymene (4.6\%), p-cymen-8-ol (0.4\%), verbenone (1.01\%), cis-carveol $(0.1 \%), \alpha$-cadinol $(6.2 \%)$, cedrol $(0.2 \%)$, 4-terpineol $(0.5 \%)$, germacrene-D $(0.4 \%), \delta$-cadinene $(0.5 \%)$ and calamenene (ND) were identified from essential oils of fresh leaves of Ipomea pes-caprae. The results of the present study confirm the presence of these sixteen compounds in the essential oil of propolis.

Additionally, epi-bicyclosesquiphellandrene, $\alpha$-campholenal, 3-isopropyl-6-methyl-2-oxo-1(3-oxobutyl)-cyclohexanecarbaldehyde and $p$-menth-1-en-8-ol were identified in both essential 
oils of Propolis collected from Haramaya and Assela. Oxygenated aromatic compound (thymol) [29], oxygenated monoterpene (camphor and borneol) [30, 31], sesquiterpenes ( $\delta$-cadinene and cedrol) [32] are the main compounds responsible for in vitro antibacterial and antifungal activity.

GC-MS analysis of hydrodistillation extract of Assela and Haramaya propolis showed similar chromatographic profile for the volatile compounds having less than $8 \min _{\mathrm{R}}$. However, variable chromatogram was observed for those components with above 16 min $t_{R}$.

Table 2. Chemical composition of essential oils of propolis obtained from Assela beehives analyzed by GC-MS

\begin{tabular}{|c|c|c|c|c|}
\hline Compound & $t_{R}(\min )$ & RI & RI Lit. & Comp. (\%) \\
\hline \multicolumn{5}{|l|}{ Oxygenated monoterpenes } \\
\hline$\alpha$-Campholenal & 5.048 & 1155 & 1123 & 0.45 \\
\hline trans-Pinocarveol & 5.261 & 1135 & 1136 & 1.10 \\
\hline cis-Verbenol & 5.297 & 1131 & 1138 & 3.37 \\
\hline Borneol & 5.623 & 1156 & 1162 & 1.05 \\
\hline 4-Terpineol & 5.766 & 1182 & 1184 & 1.79 \\
\hline$p$-Menth-1-en-8-ol & 5.952 & 1175 & --- & 1.70 \\
\hline \multicolumn{5}{|l|}{ Sesquiterpenes } \\
\hline Epi-bicyclosesquiphellandrene & 13.153 & 1470 & --- & 2.10 \\
\hline Acoradien & 20.594 & 1462 & --- & 13.77 \\
\hline Germacrene D & 21.148 & 1464 & 1475 & 1.98 \\
\hline Thujopsene & 27.717 & 1430 & --- & 1.20 \\
\hline \multicolumn{5}{|l|}{ Oxygenated sesquiterpenes } \\
\hline Epicedrol & 19.155 & 1593 & --- & 6.80 \\
\hline $\begin{array}{l}\text { 3-Isopropyl-6-methyl-2-oxo-1-(3-oxobutyl)- } \\
\text { cyclohexanecarbaldehyde }\end{array}$ & 20.456 & 1905 & --- & 4.48 \\
\hline $\begin{array}{l}\text { 2-Methyl-1-[3-methyl-6-(1-methylethylidene)- } \\
\text { 3-cyclohexen-1-yl]-3-buten-2-ol }\end{array}$ & 20.793 & 1592 & --- & 1.81 \\
\hline $\begin{array}{l}\text { 7-Acetyl-2-hydroxy-2-methyl-5- } \\
\text { isopropylbicyclo[4,3,0]nonane }\end{array}$ & 24.993 & 1685 & --- & 1.09 \\
\hline$\alpha$-Cadinol & 21.850 & 1632 & 1641 & 4.38 \\
\hline \multicolumn{5}{|l|}{ Oxygenated aromatic } \\
\hline p-Cymen-8-ol & 5.836 & 1158 & 1185 & 0.97 \\
\hline Thymol & 7.730 & 1283 & 1293 & 1.30 \\
\hline$p$-Thymol & 7.967 & 1262 & 1293 & 1.75 \\
\hline Dibutyl phthalate & 27.750 & 2094 & --- & 0.56 \\
\hline \multicolumn{5}{|l|}{ Aliphatic } \\
\hline Heptacosane & 32.275 & 2700 & 2700 & 2.14 \\
\hline Hexadecane & 35.546 & 1600 & 1600 & 3.74 \\
\hline 3-Methyl-5-propylnonane & 30.192 & 1052 & --- & 1.74 \\
\hline \multicolumn{5}{|l|}{ Oxygenated aliphatic } \\
\hline $\begin{array}{l}\text { 3,7,11-Trimethyl-3-hydroxy-6,10-dodecadien- } \\
\text { 1-yl acetate }\end{array}$ & 17.341 & 1940 & --- & 1.78 \\
\hline $\begin{array}{l}5,6,7,8 \text {-Tetramethylbicyclo }[4,1,0] \text { hept-4-en-3- } \\
\text { one }\end{array}$ & 23.499 & 1193 & --- & 15.01 \\
\hline $\begin{array}{l}\text { (6E,6E)-3,7,11,15-Tetramethyl-1,6,10,14- } \\
\text { hexadecatetraen-3-ol }\end{array}$ & 28.499 & 2056 & -- & 6.14 \\
\hline Pimar-15-en-8-yl acetate & 29.887 & 2255 & --- & 1.24 \\
\hline \multicolumn{5}{|l|}{ Others } \\
\hline 2-Nonen-1-ol & 4.687 & 1051 & --- & 0.28 \\
\hline Diazoprogesterone & 29.745 & 1811 & --- & 0.82 \\
\hline Ferruginol & 30.707 & 2226 & --- & 1.78 \\
\hline Calamenene & 15.542 & 1517 & 1520 & 4.25 \\
\hline
\end{tabular}

Bull. Chem. Soc. Ethiop. 2012, 26(3) 
Table 3. Comparison of essential oil compositions of propolis obtained from Haramaya and Assela beehives.

\begin{tabular}{|l|l|l|l|l|l|l|c|}
\hline \multicolumn{2}{|c|}{} & \multicolumn{2}{l|}{ Assela propolis } & \multicolumn{2}{l|}{ Haramaya propolis } \\
\hline Constituents & RI (iu) & RI lit. & $\mathrm{t}_{\mathrm{R}}(\mathrm{min})$ & Comp. $(\%)$ & $\mathrm{t}_{\mathrm{R}}(\mathrm{min})$ & Comp. $(\%)$ \\
\hline$\alpha$-Campholenal & 1155 & 1123 & 5.048 & 0.45 & 5.054 & 1.37 \\
\hline trans-Pinocarveol & 1135 & 1136 & 5.261 & 1.10 & 5.266 & 3.21 \\
\hline cis-Verbenol & 1131 & 1138 & 5.297 & 3.37 & 5.314 & 4.47 \\
\hline 4-Terpineol & 1182 & 1184 & 5.766 & 1.79 & 5.792 & 8.57 \\
\hline$p$-Cymen-8-ol & 1158 & 1121 & 5.836 & 0.97 & 5.864 & 3.37 \\
\hline$p$-Menth-1-en-8-ol & 1175 & --- & 5.952 & 1.70 & 5.973 & 2.87 \\
\hline Epi-bicyclosesquiphellandrene & 1470 & --- & 13.153 & 2.10 & 13.206 & 8.37 \\
\hline Calamenene & 1517 & 1520 & 15.542 & 4.25 & 15.620 & 13.82 \\
\hline $\begin{array}{l}\text { 3-Isopropyl-6-methyl-2-oxo-1-(3- } \\
\text { oxobutyl)-cyclohexanecarbaldehyde }\end{array}$ & 1905 & --- & 20.456 & 4.48 & 20.556 & 5.90 \\
\hline$\alpha$-Cadinol & 1632 & 1641 & 21.850 & 4.38 & 21.889 & 1.29 \\
\hline
\end{tabular}

In general, the difference in percentage and composition of essential oils of propolis from both collection sites could be markedly affected by the honeybee race, geographical environment, physical and chemical characteristics of soil, plant age, parts of plant that was collected by bees to make propolis.

\section{CONCLUSIONS}

A matter of great concern regarding the production and use of propolis is the variation of its chemical composition, which has motivated proposals for chemical quality control [33, 34]. This study has confirmed that most of the identified components and the composition of essential oils of Haramaya and Assela propolis are different. The forest resources, the trapping mechanism of bees, the honeybee population, distillation equipment and collection methods (traps or scraping materials) may have affected the volatile components of propolis.

Totally 62 components were identified from both oils which are classified as seven different groups namely oxygenated monoterpenes (29.81\% Haramaya, 9.45\% Assela), sesquiterpenes (15.20\% Haramaya, $19.05 \%$ Assela), oxygenated sesquiterpenes (11.86\% Haramaya, $18.56 \%$ Assela), aromatics (14.93\% Haramaya, 4.25\% Assela), oxygenated aromatics (17.59\% Haramaya, $4.58 \%$ Assela), aliphatics (5.06\% Haramaya, 7.62\% Assela) and oxygenated aliphatics (7.84\% Haramaya, 25.17\% Assela). From 62 compounds identified, 27 among of them were found for the first time in essential oils of propolis.

\section{ACKNOWLEDGEMENTS}

We wish to thank Dr. Tarekegn Berhanu and W/t Esrael Habtu for their help in running GC-MS experiment at the Quality and Standards Authority of Ethiopia. The financial assistance from Ministry of Education of Ethiopia is gratefully acknowledged.

\section{REFERENCES}

1. Park, Y.K.; Alencar, S.M.; Aguiar, C.L. J. Agric. Food Chem. 2002, 25, 2502.

2. Gomez-Caravaca, A.M.; Goomez-Romero, M.; Arraez Roman, D.; Segura-Carretero, A.; Fernandez Gutierrez, A. J. Pharm. Biomed. Ana. 2006, 41, 1220.

3. Suzuki, I.; Hayashi, I.; Takaki, T.; Groveman, D.S.; Fujimiya, Y. Cancer Biother. Radiopharm. 2002, 17, 553. 
4. Burdock, G.A. Food Chem. Toxicol. 1998, 36, 347.

5. Marcucci, M.C. Apidologie 1995, 26, 83.

6. Almeida, E.C.; Menezes, H. J. Venom. Anim. Toxins. 2002, 8, 191.

7. Markham, K.E.; Mitchel, K.A.; Wilkins, A.L.; Daldy, J.A.; Lu, Y. Phytochemistry 1996, 42, 205.

8. Bankova, V.; Dyulgerov, A.; Popov, S.; Evstatieva, L.; Kuleva, L.; Purb, O.; Zamjansan, Z. Apidologie 1992, 23, 79.

9. Marcucci, M.C.; Ferreres, F.; Garcia-Viguera, C.; Bankova, V.S.; De Castro, S.L.; Dantas, A.P.; Valente, P.H.M.; Paulino, N. J. Ethnopharmacol. 2001, 74, 105.

10. Bankova, V. Z. Naturforsch. 1994, 49, 6.

11. Ferracini, V.L. J. Essent. Oil Res. 1995, 7, 355.

12. Cuesta-Rubio, O.; Frontana-Uribe, B.A.; Ramirez-Apan, T.; Cardenas, J. Z. Naturforsch. 2002, 57, 372.

13. Lorenzo, C.G. M.Sc. Thesis, University of the Witwatersrand, South Africa, 2008, pp 51-66.

14. Hegazi, A.G.; Abd El Hady, F.K. Z. Naturforsch. 2002, 57c, 395.

15. Oliveira, A.P.; França, H.S.; Kuster, R.M.; Teixeira, L.A.; Rocha, L.M. J. Venom. Anim. Toxins incl. Trop. Dis. 2010, 16, 121.

16. Sime, D. M.Sc. Thesis, Addis Ababa University, Ethiopia, 2007, pp 16-20.

17. Alemaya University of Agriculture (AUA), Proceeding of the $15^{\text {th }}$ Annual Research and Extension Review meeting, Alemaya University, Alemaya, Ethiopia. 1998, pp 10-20.

18. Demel, T. Plants Recorded from the Alemaya University of Agriculture (AUA) Campus. 1988, pp 10- 14 .

19. Kulumsa Agricultiral Research Center (KARC), Annual Reports of Kulumsa Agricultiral Research Center. Assela, Ethiopia, 2008, pp 105-110.

20. Marostica, M.R.; Junior, A.D.; Cleber, S.M.; Carmen, L.Q.; Glaucia, M.P.; Yong, K.P. Cienc. Tecnol. Aliment. 2008, 28, 178.

21. Bankova, V.; Christov, R.; Trusheva, B.; Popova, M.; Bankova, V.; Bertrand, M. Nat. Prod. Res. 2005, 19, 673.

22. Meiling, Q.; Daniel, W. A. Anal. Bioanal. Chem. 2007, 388, 889.

23. Ayalew, K. M.Sc. Thesis, Agricultural University of Norway, Norway, 1990, pp 15-19.

24. Amsalu, B.; Nuru, A.; Radloff, S.E.; Hepburn, H.R. Apidologie 2004, 35, 71.

25. Bankova, V.; Boudourova-Krasteva, G.; Sforcin, J.M. Z. Naturforsch. 1999, 54, 401.

26. Jamshidi, R.; Afzali, Z.; Afzali, D. Am-Euras. J. Agric. Environ. Sci. 2009, 5, 78.

27. Rolando, M.; Jorge, A.P.; America, D.; Carlos, Z.; Enrique, S. J. Essent. Oil Res. 2006, 18, 53.

28. Marie, D.E.; Dejan, B.; Quetin-Leclercq, J. Nat. Prod. Commun. 2007, 2, 1225.

29. Vila, R.; Valenzuela, L.; Bello, H.; Canigueral, S.; Montes, M.; Adzet, T. Planta. Med. 1999, 65, 178 .

30. Pintore, G. Flavour Fragr J. 2002, 17, 15.

31. Genena, A.K.; Hense, H.; Junior, A.S.; Souza, S.M. Cienc. Tecnol. Aliment. Campinas, 2008, 28, 463.

32. Eleni, M.; Eleftherios, S.; Ioanna, C. Food Chem. 2007, 103, 375.

33. Woisky, R.G.; Salatino, A. J. Apic. Res. 1998, 37, 99.

34. Bankova, V.S.; Decastro, S.L.; Marcucci, M.C. Apidologie 2000, 31, 3. 